\title{
Ataxia-pancytopenia syndrome
}

INSERM

\section{Source}

INSERM. (1999). Orphanet: an online rare disease and orphan drug data base. Ataxiapancytopenia syndrome. ORPHA:2585

Ataxia-pancytopenia syndrome is a rare genetic disease characterized by cerebellar ataxia, cytopenias and predisposition to bone marrow failure and myeloid leukaemia. Neurologic features variably include slowly progressive cerebellar ataxia or balance impairment with cerebellar atrophy and periventricular white matter T2 hyperintensities in brain MRI, horizontal and vertical nystagmus, dysmetria, dysarthria, pyramidal tract signs and reduced nerve conduction velocity. Hematological abnormalities are variable and may be intermittent and include cytopenias of all cell lineages, immunodeficiency, myelodysplasia and acute myeloid leukemia. 